\title{
Connective Ending Awareness of Early School-Aged Children at Risk for Specific Language Impairment
}

\author{
Ji Hye Park ${ }^{\mathrm{a}}$, Young Tae Kim ${ }^{\mathrm{a}, \mathrm{b}}$, Seok Jeong Yeon ${ }^{\mathrm{b}}$ \\ ${ }^{a}$ Department of Communication Disorders, Ewha Womans University, Seoul, Korea \\ ${ }^{b}$ Children's Center for Developmental Support, Ewha Womans University, Seoul, Korea
}

Correspondence: Young Tae Kim, PhD Department of Communication Disorders, Ewha Womans University, 52 Ewhayeodae-gil, Seodaemun-gu, Seoul 03760, Korea Tel: $+82-2-3277-2120$

Fax: +82-2-3277-2122

E-mail: youngtae@ewha.ac.kr

Received: October 5, 2018

Revised: November 10, 2018

Accepted: November 27, 2018
Objectives: The purpose of this study is to examine the connective ending awareness of early school-aged children who understood primary Korean sentence structure and continuously develop grammatical awareness. Also, this study compares the ability between children at risk for specific language impairment and typically developing children. Methods: Thirty-two 1st-3rd grade children in elementary school children participated in this study: 16 children at risk for specific language impairment (AR-SLI group) and 16 age- and gender-matched typically developing children (TD group). The connective ending awareness test consisted of four tasks (change, judgement, correction, word-order), and in each task the same number of coordinate and subordinate endings were assigned. The connective ending awareness test was analyzed by using a three-way mixed ANOVA according to the group, task type, and connective ending type. Also, the correlation among connective ending awareness, vocabulary, syntactic comprehension ability, and syntactic production ability were analyzed using a Pearson correlation coefficient. Results: It is showed that connective ending awareness has a significant main effect of groups, task types, and connective ending types; and that the AR-SLI group showed lower ability than the TD group. The connective ending awareness of the AR-SLI group was found to have a significant positive correlation with expressive vocabulary and syntactic production ability. Conclusion: The results of this study indicate that the AR-SLI group with delayed vocabulary, similar to SLI, showed difficulty in syntactic ability. In addition, the connective ending awareness test can be used as a tool to evaluate the syntactic abilities of school-aged children.

Keywords: Children at risk for specific language impairment, Connective ending, Metalinguistic awareness 단순언어장애(specific language impairment, SLI) 아동은 지능 이나 청각, 신경학적인 문제나 사회적 상호작용 능력에 이상이 없으 면서 언어발달에서만 어려움을 보이며(Leonard, 2014), 또래 아동 에 비해 언어능력이 지체되어 있고, 특히 형태통사적(morphosyn$\operatorname{tax}$ ) 능력이 제한되어 있다(Rice, Wexler, \& Redmood, 1999). 이들 은 문법형태소 습득에서의 어려움(Tomas, Demuth, \& Petocz, 2017) 뿐만 아니라 복문을 사용하는 것에도 어려움을 나타내고(Marinellie, 2004), 연령이 증가함에 따라 구문적인 능력이 향상되지만 여전히 또래에 비해 낮은 수준으로 나타난다(Rice et al., 1999). 단 순언어장애 아동은 읽기를 통한 학습이 중요해지는 학령기에 들어
서 언어학습장애로 이어질 가능성이 있다(Nippold, 2017)는 점에 서 학령기로 전환되는 단순언어장애 아동의 언어능력에 대한 지속 적인 연구가 필요하다.

한국어의 연결어미는 문법형태소 중 하나로 그 쓰임에 따라 통사 론적인 단위가 될 수도 있고, 형태론적인 단위가 될 수도 있는 이중 적인 기능을 지니고 있다(Nam, 2001). 또한, 연결어미는 주로 문법 적인 기능을 나타내지만 어휘적인 의미도 가지는 요소이며(Nam et al., 2004), 그 종류가 다양하고 수가 많으며 복잡한 문장을 만들거 나 이야기를 응집성 있게 전개하기 위해 필수적으로 사용하는 문 법형태소이다. 연결어미와 관련된 선행연구는 자발화나 이야기 산 
출과제(Chung, 2013; Pae, 2006), 그림을 통한 연결어미 이해 및 산 출 특성 확인 과제(Cho, 2007; Kim, 2002) 등을 통해 연령별, 집단 별 특징을 확인해 볼 수 있다. 최근에는 연결어미의 문법인식과 관 련된 연구(Jung \& Pae, 2010; Kim, 2015; Lee, Jeong, \& Hwang, 2013)도 보고되고 있으며, 연결어미를 인식하고 조작하는 능력은 연결어미에 관한 지식 및 연결어미의 실질적인 사용에 도움을 줄 수 있다. 문법인식은 메타언어인식(metalinguistic awareness)의 한 종류로, 메타언어인식은 언어를 사고의 대상으로 다루고, 언어의 구조적 속성이나 특성에 대해 성찰할 수 있는 능력을 의미한다 (Tunmer \& Herriman, 1984). 문법인식은 문법 단위에 따라 형태소 인식(morphological awareness), 구문인식(syntactic awareness)으 로 나눌 수 있고(Tong, Deacon, \& Cain, 2014), 선행연구들에서는 문법인식이 상대적으로 늦게 발달하여 6-8세에 이르러야 가능하 며(Kamhi, 1987; Kamhi \& Koenig, 1985; Smith \& Tager-Flusberg, 1982 ), 학령기 이후로도 계속 발달하는 것으로 나타났다(Cain, 2007; Cho, 2007; Chung, 2016; Deacon \& Kieffer, 2018; Varghese \& Venkatesh, 2012). 연결어미는 종류와 수가 많기에 이를 대상으로 하는 문법인식에 관한 연구가 보다 다양하게 진행될 필요가 있으며, 어휘력 지연을 보이는 학령기 단순언어장애 위험 아동을 대상으로 한 연구도 필요하다.

한 연구(Hadley \& Short, 2005)에서는 언어발달장애로 진단되지 않더라도, 둘 혹은 그 이상의 표준화된 언어검사에서 낮은 수준을 보이는 아동을 단순언어장애 위험 아동으로 정의하고, 영유아기 단순언어장애 위험 아동의 문법표지 사용을 대상으로 단순언어장 애 변별과 관련된 연구를 진행하였다. 이와 대상군의 연령은 다르 지만 본 연구에서는 학령기의 정상 지능인 아동 중에서 어휘력 지 연을 보이는 아동도 단순언어장애로 진단될 위험이 있을 것이라 예 상하여, 이들을 단순언어장애 위험 아동으로 정의하고, 연결어미 인식검사를 통해 이들의 문법인식 능력의 특성을 확인하고자 하였 다. 단순언어장애 위험 아동이 일반아동과 달리 구문능력에서도 어려움을 보인다면 학령기 단순언어장애 아동의 특성을 이해하는 데 도움이 될 수 있다. 이에 어휘력 지연을 보이는 단순언어장애 위 험 아동의 특성이 일반아동과 어떻게 다른지 알아보고, 단순언어 장애 아동의 특성과 비슷한 점이 있는지 알아보고자 하였다. 또한 연결어미 인식 능력, 어휘력, 구문능력의 상관관계를 확인하여 어 휘력 지연을 보이는 단순언어장애 위험 아동과 일반아동의 차이를 비교해보고자 하였다.

이에 본 연구에서는 기본적인 한국어의 구문지식이 습득되었고 문법인식이 지속적으로 발달하는 초등학교 저학년 단순언어장애 위험 아동과 생활연령과 성별을 일치시킨 일반아동의 연결어미 인
식 능력을 비교하여 알아보고자 하였다. 이에 따른 연구문제는 다 음과같다.

1) 집단(단순언어장애 위험 아동, 일반아동) 간 연결어미 유형(대 등적 연결어미, 종속적 연결어미)과 연결어미 인식 과제 유형 (변환, 판단, 수정, 배열)에 따라 연결어미 인식 능력에 유의한 차이를 보이는가?

2) 집단(단순언어장애 위험 아동, 일반아동) 간 과제에 따른 연결 어미 인식 능력과 어휘력은 구문이해능력 및 구문산출능력과 어떠한 상관이 있는가?

\section{연구방법}

\section{연구대상}

본 연구의 대상은 초등학교 1-3학년 단순언어장애 위험 아동 16 명, 생활연령과 성별을 일치시킨 일반아동 16 명, 총 32 명으로 하였 다. 문법인식이 6-8세에 이르러야 가능하고(Kamhi, 1987; Kamhi \& Koenig, 1985; Smith \& Tager-Flusberg, 1982), 학령기 동안 지속 적으로 발달한다(Cain, 2007; Deacon \& Kieffer, 2018; Jeong, 2010) 는 선행연구에 따라 기본적인 한국어의 구문지식이 습득되었고 문 법인식 능력이 지속적으로 발달하는 초등학교 저학년 아동을 대상 자로 선정하였다. 또한, 본 연구의 실험과제 중 배열과제는 제시된 단어카드를 사용하여 구문적, 의미적으로 올바른 문장이 되도록 배열해야하므로 읽기가 가능한 아동을 연구대상자로 선정하였다.

단순언어장애 위험 아동은 (1) 부모나 교사에 의해 언어문제가 있는 것으로 보고받은 아동 중에서, (2) 한국 비언어지능검사(KCTONI-2; Park, 2014)의 도형척도 비언어 지능검사 결과 85 이상이 고, (3) 수용·표현어휘력검사(REVT; Kim, Hong, Kim, Jang, \& Lee, 2009) 결과 수용어휘력 또는 표현어휘력이 -1.25 SD 미만이며, (4) 청각이나 신경학적 문제가 없고, 정서-행동상의 문제가 없다고 보 고된 아동으로 선정하였다.

일반아동은 (1) 부모나 교사에 의해 정상발달하는 것으로 보고 된 아동 중에서, (2) 한국 비언어지능검사(K-CTONI-2)의 도형척도 비언어 지능검사 결과 85 이상이고, (3) 수용·표현어휘력검사(REVT) 결과 수용 및 표현어휘력이 모두 -1 SD 이상이며, (4) 청각이나 신경 학적 문제가 없고, 정서.행동상의 문제가 없다고 보고된 아동으로, (5) 생활연령이 단순언어장애 위험 아동과 비교하여 \pm 6 개월 범위 내에 속하는 아동으로 선정하였다. 본 연구에 참여한 집단별 대상 자의 기본 정보는 Table 1 에 제시하였다.

집단 간 변인의 동일성을 검증하고자 독립표본 $t$-검정(independent sample $t$-test)을 실시하였다. 그 결과, 단순언어장애 위험 아동 
Table 1. Participants' characteristics

\begin{tabular}{lccc}
\hline Characteristic & AR-SLI (N=16) & TD (N=16) & $t$ \\
\hline Age (mo) & $94.31(9.49)$ & $94.75(7.82)$ & -.142 \\
Nonverbal intelligence & $101.50(7.69)$ & $105.19(12.18)$ & -1.024 \\
Sex & & & \\
$\quad$ Male & 9 & 9 & \\
$\quad$ Female & 7 & 7 & \\
Receptive vocabulary & $76.69(13.59)$ & $97.38(16.85)$ & $-3.823^{\text {b* }}$ \\
Expressive vocabulary $^{b}$ & $78.81(10.94)$ & $94.88(17.39)$ & $-3.127^{* *}$ \\
\hline
\end{tabular}

Values are presented as mean (SD).

AR-SLI = children at risk for specific language impairment; $T D$ = typically developing children.

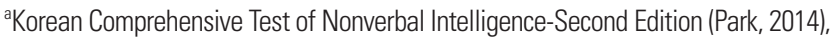

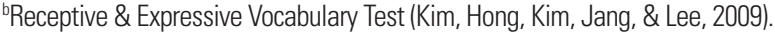
${ }^{* *} p<.01$.

과 일반아동 간 생활연령과 비언어 지능지수에서는 유의한 차이를 보이지 않았으며 $(p>.05)$, 수용어휘력 원점수 $(t=-3.823, p<.01)$ 와 표현어휘력 원점수 $(t=-3.127, p<.01)$ 는 집단 간 유의한 차이가 나 타나 단순언어장애 위험 아동의 평균이 일반아동보다 유의하게 낮 은 것으로 나타났다.

\section{연구도구 및 절차}

\section{연결어미 인식검사 도구}

연결어미 인식검사는 변환과제, 판단과제, 수정과제 및 배열과제 총 4 개로 구성하여 각각의 과제에 대등적 연결어미(예: 나열, 동시, 대립)와종속적 연결어미(예: 이유·원인, 조건, 목적)의 수를 동일하 게 배치하였다. 연결어미 인식검사는 선행연구(Cho, 2007; Kim, 2002; Kim, 2015; Lee et al., 2013)와 학령기 아동 언어검사(LSSC; Lee, Heo, \& Jang, 2014)의 문항을 참고하여 연구자가 수정·보완하 여 개발하였다. 본 실험을 진행하기 전에 과제 진행상의 어려움은 없는지 확인해 보고자 일반아동 3 명을 대상으로 예비실험을 진행 하였고, 배열과제 예비실험에서 문장 구성에 어려워하는 아동이 있 어 단어카드를 1 줄로 배열하여 문장을 완성할 수 있도록 가로로 긴 단어배열판 $(75 \mathrm{~cm} \times 10 \mathrm{~cm})$ 으로 수정하였다. 연결어미 인식검사는 전문가 3 인(1급 언어재활사자격증을 소지한 언어병리학 박사과정) 에게 5점 척도를사용하여 내용타당도를 평가받았으며, Fehring (1987) 에 따라 각 점수별 가중치 $(1$ 점 $=0,2$ 점 $=.25,3$ 점 $=.5,4$ 점 $=.75,5$ 점 $=1.00$ )를 부여하여 문항마다 평균 점수를 산출하였다. 그 결과 평 균 .90점으로 평가되어 높은 내용타당도를 보이는 것으로 나타났다.

변환과제는 태블릿 $\mathrm{PC}$ 로 제시된 문항을 보고 연결어미에 맞게 동사를 변환하도록 하였고, 판단과제는 목표 연결어미가 아닌 다 른 의미관계의 연결어미가 포함된 문장을 듣고 정오를 판단하도록
하였다. 수정과제는 부적절한 의미관계의 연결어미를 내용상 어울 리는 정확한 연결어미로 수정하여 표현하도록 하였고, 배열과제는 무작위의 단어카드를 문장구조에 맞게 조작하여 한 문장으로 제 시하도록 하였다. 검사 시 연습문항을 먼저 제시하여 아동이 검사 진행방식을 익힌 후에 본 검사를 진행하도록 하였으며 원활한 검사 진행을 위하여 판단과제와 수정과제는 동시에 진행하였다. 연결어 미 인식검사의 예는 Appendix 1에 제시하였다.

\section{구문이해 및 구문산출능력 검사}

구문이해 및 구문산출능력 검사는 학령기 아동언어검사(LSSC) 의 ‘구문이해'와 ‘복문산출'의 하위 검사 문항 중에서 연결어미와 관련된 문항을 연구자가 선별하여 각각 16 문항으로 구성하였다. 구문이해능력 검사는 태블릿 PC로 제시된 그림을 보고 들려주는 문장과 일치하는 그림을 고르도록 하였으며, 구문산출능력 검사 는 연구자가 제시하는 2-3개의 짧은 문장을 듣고 한 문장으로 표현 하도록 하였다. 검사 시 연습문항을 먼저 제시하여 아동이 검사 진 행방식을 익힌 후에 본 검사를 진행하도록 하였다.

\section{검사절차}

검사는 서울, 경기, 충남지역의 초등학교 또는 아동의 집에서 별 도의 조용한 장소에서 연구자와 아동이 일대일로 진행하였으며, 대 상자 선정을 위한 기초검사(비언어지능검사, 어휘력검사)를 진행한 후 본 검사를 진행하였다. 본 검사는 연결어미 인식검사, 구문이해 능력 검사, 구문산출능력 검사 순으로 진행하였다.

\section{자료분석 및 결과처리}

연결어미 인식검사는 각 과제별로 정반응한 경우 1 점, 오반응한 경우 0 점으로 채점하여 총점을 산출하였다. 각 과제별 총점은 변환 과제 30 점, 판단과제 18 점, 수정과제 12 점, 배열과제 12 점이며, 정반 응률(\%)은 아동이 정반응한 응답의 수를 목표 문항의 수로 나눈 후 100 을 곱하여 계산하였다.

구문이해 및 구문산출능력 검사는 정반응한 경우 1점, 오반응한 경우 0 점으로 채점하여 총점을 산출하였으며, 각 과제의 총점은 16 점이다. 정반응률(\%)은 아동이 정반응한 응답의 수를 목표 문항의 수로 나눈 후 100 을 곱하여 계산하였다.

집단, 과제 유형, 연결어미 유형에 따른 연결어미 인식 능력의 차 이 분석을 위하여 삼원혼합분산분석(three-way mixed ANOVA) 을 실시하였고, 연결어미 인식검사와 어휘력, 구문이해 및 구문산 출능력의 상관을 분석하기 위해 피어슨(Pearson) 상관분석을 실시 하였다. 


\section{신뢰도}

신뢰도는 평가자 간 신뢰도의 일치율(\%)을 구하여 산출하였고, 제 1 평가자는 연구자이며, 제 2 평가자는 언어병리학을 전공하는 대 학원생이었다. 전체 자료 중 $20 \%$ 를 무선 추출하여 녹음된 내용을 듣고 채점하도록 하였으며, 평가자 간 평가 결과가 일치한 항목 수 를 전체 항목수로 나눈 후 100 을 곱하여 산출하였다. 평가자 간 신 뢰도는 연결어미 인식검사 평균 $97.22 \%$, 구문이해능력 검사 $100 \%$, 구문산출능력 검사 $91.67 \%$ 로 검사 수행점수에 대한 평가자 간 신 뢰도는 평균 $96.79 \%$ 로 나타났다.

\section{연구결과}

\section{연결어미 인식 능력}

집단 간 연결어미 유형과 연결어미 인식과제 유형에 따른 연결어 미 인식 능력이 통계적으로 유의한 차이가 있는지 검증하기 위해 집단(2) $\times$ 연결어미 인식과제 유형(4) $\times$ 연결어미 유형(2)의 삼원혼 합분산분석(three-way mixed ANOVA)을 실시하였다. 그 결과, 집 단 $\left(F_{(1,30)}=10.955, p<.01\right)$, 과제 유형 $\left(F_{(3,90)}=68.655, p<.01\right)$, 어미 유형 $\left(F_{(1,30)}=46.006, p<.01\right)$ 의 주효과가 유의하였다. 즉, 단순언어 장애 위험 아동의 연결어미 인식 점수가 일반아동보다 유의하게 더 낮은 것으로 나타났으며, 대등적 연결어미의 점수가 종속적 연결어 미의 점수에 비해 유의하게 더 높은 것으로 나타났다. 4 개의 과제 유형에 따른 연결어미 인식 능력의 주효과가 유의하였기에 Bonferroni 사후검정을 실시한 결과, 수정과제와 변환과제, 판단과제, 배 열과제 간에 통계적으로 유의한 차이가 있는 것으로 나타났다 $(p<.01)$. 즉 수정과제의 점수가 다른 과제의 점수보다 유의하게 더
낮은 것으로 나타났다. 집단, 연결어미 인식과제 유형, 연결어미 유형 에 따른 연결어미 인식 능력의 기술적 통계는 Table 2에 제시하였다.

과제 유형과 어미 유형의 상호작용 효과가 통계적으로 유의한 것 으로 나타났다 $\left(F_{(3,90)}=3.991, p<.05\right)$. 모든 과제 유형에서 대등적 연결어미의 수행점수가 종속적 연결어미의 수행점수보다 높게 나 타났다. 연결어미 인식과제 유형별로 일원배치분산분석(one-way ANOVA)을 실시한 결과, 연결어미 유형 간에는 변환과제 $\left(F_{(1,62)}=\right.$ $11.187, p<.01)$, 배열과제 $\left(F_{(1,62)}=6.395, p<.05\right)$ 에서 차이가 유의하 게 나타났다. 집단 간에는 변환과제의 대등적 연결어미 유형 $\left(F_{(1,30)}=\right.$ $14.314, p<.01)$ 과 종속적 연결어미 유형 $\left(F_{(1,30)}=5.896, p<.05\right)$, 판 단과제의 대등적 연결어미 유형 $\left(F_{(1,30)}=5.554, p<.05\right)$ 과 종속적 연 결어미 유형 $\left(F_{(1,30)}=5.906, p<.05\right)$, 수정과제의 대등적 연결어미 유 형 $\left(F_{(1,30)}=7.204, p<.05\right)$ 과 종속적 연결어미 유형 $\left(F_{(1,30)}=6.292\right.$, $p<.05)$ 에서 차이가 유의하게 나타났고, 배열과제의 대등적 연결어

Table 2. Descriptive statistics of connective ending awareness ability (\%)

\begin{tabular}{llcl}
\hline Task type & Connective ending type & AR-SLI (N=16) & TD (N=16) \\
\hline Change task & Coordinate & $74.17(18.03)$ & $93.75(10.17)$ \\
& Subordinate & $60.83(19.15)$ & $76.25(16.68)$ \\
Judgement task & Coordinate & $72.92(17.20)$ & $86.11(14.34)$ \\
& Subordinate & $70.83(18.98)$ & $84.72(12.75)$ \\
Correction task & Coordinate & $28.13(30.86)$ & $58.33(32.77)$ \\
& Subordinate & $18.75(20.07)$ & $40.63(28.52)$ \\
Word-order task & Coordinate & $72.92(27.13)$ & $87.50(19.72)$ \\
& Subordinate & $58.33(22.77)$ & $72.92(18.13)$ \\
\hline
\end{tabular}

Values are presented as mean (SD).

AR-SLI= children at risk for specific language impairment; $T D=$ typically developing children.

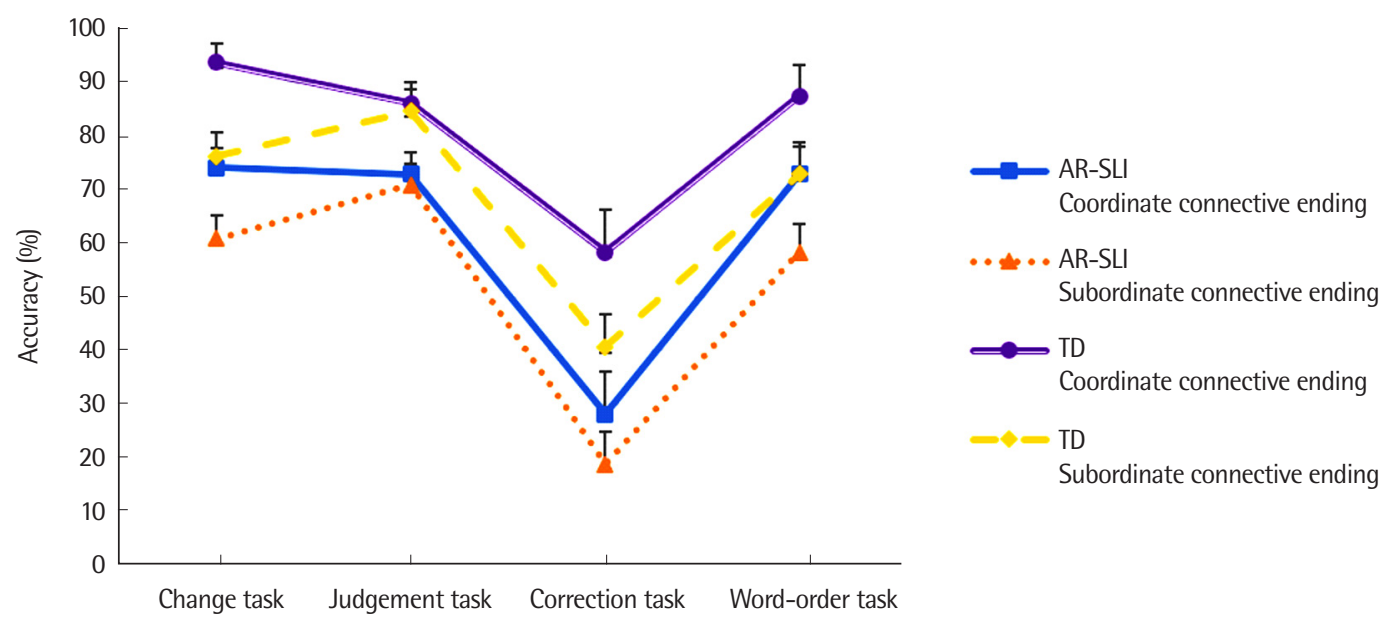

Figure 1. Interaction of task type and connective ending type.

AR-SLI= children at risk for specific language impairment; $T D=$ typically developing children . 
미 유형과 종속적 연결어미 유형에서는 집단 간 차이가 유의하지 않게 나타났다 $(p>.05)$. 연결어미 인식과제 유형과 연결어미 유형의 상호작용 효과 그래프는 Figure 1에 제시하였다.

\section{연결어미 인식 능력과 어휘력 및 구문능력과의 상관관계}

두 집단 간 구문이해능력과 구문산출능력의 차이를 알아보기 위해 독립표본 $t$-검정(independent sample $t$-test)을 실시한 결과 구 문이해능력은 두 집단 모두 높은 수행을 보여 집단 간 유의한 차이 가 나타나지 않았으나 $(p>.05)$, 구문산출능력은 단순언어장애 위 험 아동이 일반아동보다 유의하게 낮은 수행을 보이는 것으로 나

Table 3. Descriptive statistics of syntactic ability (\%)

\begin{tabular}{llll}
\hline & AR-SLI (N=16) & TD (N=16) & \multicolumn{1}{c}{$t$} \\
\hline Syntactic comprehension test & $88.67(7.64)$ & $92.58(8.30)$ & -1.385 \\
Syntactic production test & $41.41(17.06)$ & $60.94(19.57)$ & $-3.010^{* *}$ \\
\hline
\end{tabular}

Values are presented as mean (SD).

AR-SLI = children at risk for specific language impairment; $T D$ = typically developing children.

${ }^{* * *} p<.01$.
타났다 $(t=-3.010, p<.01)$. 두 집단의 구문이해능력과 구문산출능 력 점수의 기술통계 결과와 $t$-검정 결과는 Table 3 에 제시하였다.

단순언어장애 위험 아동의 과제에 따른 연결어미 인식 능력과 어 휘력이 구문이해능력 및 구문산출능력과 어떠한 상관관계를 나타 내는지 알아보기 위하여 피어슨(Pearson) 적률상관분석을 실시하 였다. 단순언어장애 위험 아동의 구문이해능력은 연결어미 인식 능 력과 어휘력 간에는 유의한 상관관계가 나타나지 않았다 $(p>.05)$. 구문산출능력은 연결어미 인식 능력 중 변환과제 수행력 $(r=.587$, $p<.05)$, 판단과제 수행력 $(r=.503, p<.05)$, 수정과제 수행력 $(r=.680$, $p<.01)$, 배열과제 수행력 $(r=.521, p<.05) 4$ 개의 과제 모두에서 정 적상관을 보였으며, 표현어휘력 $(r=.540, p<.05)$ 과도 정적상관을 보였다. 즉, 연결어미 인식과제 수행력 점수와 표현어휘력 점수가 높 을수록 구문산출능력의 점수가 높은 것으로 나타났다. 단순언어장 애 위험 아동의 변인 간 상관관계 분석결과는 Table 4에 제시하였다.

일반아동의 과제에 따른 연결어미 인식 능력과 어휘력이 구문이 해능력 및 구문산출능력과 어떠한 상관관계를 나타내는지 알아보 기 위하여 피어슨(Pearson) 적률상관분석을 실시하였다.

일반아동의 구문이해능력은 연결어미 인식 능력과 어휘력 간에

Table 4. Correlation coefficient between variables of AR-SLI group

\begin{tabular}{|c|c|c|c|c|c|c|c|}
\hline & $\begin{array}{l}\text { Change } \\
\text { task }\end{array}$ & $\begin{array}{l}\text { Judgement } \\
\text { task }\end{array}$ & $\begin{array}{c}\text { Correction } \\
\text { task }\end{array}$ & $\begin{array}{l}\text { Word-order } \\
\text { task }\end{array}$ & $\begin{array}{l}\text { Receptive } \\
\text { vocabulary }^{\text {a }}\end{array}$ & $\begin{array}{l}\text { Expressive } \\
\text { vocabulary }^{\mathrm{a}}\end{array}$ & $\begin{array}{c}\text { Syntactic } \\
\text { comprehension }\end{array}$ \\
\hline Judgement task & .471 & & & & & & \\
\hline Correction task & .338 & $.668^{* *}$ & & & & & \\
\hline Word-order task & $.873^{* *}$ & .435 & .355 & & & & \\
\hline Receptive vocabulary ${ }^{a}$ & .019 & .252 & $.519^{*}$ & -.157 & & & \\
\hline Expressive vocabulary ${ }^{a}$ & .464 & .213 & .360 & .288 & $.508^{*}$ & & \\
\hline Syntactic comprehension & -.193 & -.014 & -.478 & -.398 & -.105 & -.082 & \\
\hline Syntactic production & $.587^{*}$ & $.503^{*}$ & $.680^{* *}$ & $.521^{*}$ & .451 & $.540 *$ & -.297 \\
\hline
\end{tabular}

AR-SLI = children at risk for specific language impairment.

aReceptive \& Expressive Vocabulary Test (Kim, Hong, Kim, Jang, \& Lee, 2009).

${ }^{*} p<.05,{ }^{* *} p<.01$.

Table 5. Correlation coefficient between variables of TD group

\begin{tabular}{|c|c|c|c|c|c|c|c|}
\hline & $\begin{array}{l}\text { Change } \\
\text { task }\end{array}$ & $\begin{array}{l}\text { Judgement } \\
\text { task }\end{array}$ & $\begin{array}{l}\text { Correction } \\
\text { task }\end{array}$ & $\begin{array}{c}\text { Word-order } \\
\text { task }\end{array}$ & $\begin{array}{c}\text { Receptive } \\
\text { vocabulary }\end{array}$ & $\begin{array}{l}\text { Expressive } \\
\text { vocabulary }\end{array}$ & $\begin{array}{c}\text { Syntactic } \\
\text { comprehension }\end{array}$ \\
\hline Judgement task & $.712^{* *}$ & & & & & & \\
\hline Correction task & $.579^{*}$ & $.760^{* *}$ & & & & & \\
\hline Word-order task & $.786^{* *}$ & $.742^{* *}$ & .439 & & & & \\
\hline Receptive vocabulary ${ }^{a}$ & $.526^{*}$ & .387 & $.546^{*}$ & .267 & & & \\
\hline Expressive vocabulary ${ }^{a}$ & $.539^{*}$ & $.545^{*}$ & $.680^{* *}$ & .291 & $.871^{* *}$ & & \\
\hline Syntactic comprehension & .249 & .378 & .481 & .143 & .126 & .368 & \\
\hline Syntactic production & .474 & $.659^{* *}$ & $.575^{*}$ & $.553^{*}$ & .301 & .402 & .132 \\
\hline
\end{tabular}

TD = typically developing children.

aReceptive \& Expressive Vocabulary Test (Kim, Hong, Kim, Jang, \& Lee, 2009).

${ }^{*} p<.05,{ }^{* *} p<.01$. 
는 유의한 상관관계가 나타나지 않았다 $(p>$.05). 구문산출능력은 연결어미 인식 능력 중 판단과제 수행력 $(r=.659, p<.01)$, 수정과제 수행력 $(r=.575, p<.05)$, 배열과제 수행력 $(r=.553, p<.05) 3$ 개의 과 제에서 정적상관을 보였으며, 어휘력과는 유의한 상관관계가 나타 나지 않았다. 즉, 연결어미 인식과제 수행력 점수가 높을수록 구문 산출능력의 점수가 높은 것으로 나타났다. 일반아동의 변인 간 상 관관계 분석 결과는 Table 5 에 제시하였다.

\section{논의 및 결론}

본 연구는 연결어미 인식검사를 통하여 단순언어장애 위험 아동 과 일반아동의 연결어미 인식 능력을 비교하고, 연결어미 인식 능력 과어휘력, 구문이해능력 및 구문산출능력의상관관계를 살펴보았다.

본 연구결과, 단순언어장애 위험 아동은 일반아동에 비해 연결 어미 인식 능력이 낮게 나타났다. 이는 단순언어장애 아동이 형태 통사적 능력에 제한이 있고, 문법형태소 습득 및 복문 사용 등 구 문능력에 어려움을 보인다는 선행연구 결과(Leonard, 2014; Marinellie, 2004; Rice et al., 1999; Tomas et al., 2017)와 유사하다. 어휘 력 지연을 보이는 단순언어장애 위험 아동도 단순언어장애 아동과 같은 특성을 공유한다는 것을 확인할 수 있었다. 연결어미 인식과 제는 사후검정 결과 수정과제로부터 차이가 나타났는데, 문법성 판단 및 수정 과제를 진행한 선행연구에서는 전반적으로 수정과제 에서의 수행력이 더 낮게 나타났다(Jung \& Pae, 2010; Tsang \& Stokes, 2001; Varghese \& Venkatesh, 2012). 수정을 위해서는 판단을 할 때 보다 작업기억에 문장을 더 오래 유지해야 하고, 반응을 명확히 표 현해야하기에 인지적으로 더 부담스럽기 때문이다(Tsang \& Stokes, 2001; Varghese \& Venkatesh, 2012). 수정과제의 경우 판단과제보 다 더 높은 수준의 처리 용량을 필요로 하기에(Tsang \& Stokes, 2001) 수정과제에서의 수행력이 낮게 나타난 것이다. 과제 유형별 로 요구되는 처리 용량 수준이 다르며(Cain, 2007; Tsang \& Stokes, 2001), 과제를 제시하는 방법에 따라 요구되는 기억 및 처리 수준이 달라지고 그 결과 수행력에 차이가 나타난다. 이는 구어로 문장을 들려주고 부적절한 의미관계의 연결어미를 내용에 맞는 정확한 연 결어미로 수정을 요구한 수정과제에서 두 집단이 모두 낮은 수행력 을 보여 다른 과제 유형과 유의한 차이를 나타냈다는 결과와 관련 지어 설명할 수 있다.

대등적 연결어미가 포함된 문항의 점수가 종속적 연결어미가 포 함된 문항의 점수에 비해 유의하게 더 높은 것으로 나타났다. 선행 연구(Chung, 2013; Pae, 2006; Seo \& Lee, 1999)에 따르면 발달 순서 의 차이는 있지만 일반적으로 대등적 연결어미가 2-3세경에 발달
하고, 종속적 연결어미는 3세경부터 발달하기 시작하여 연령이 증 가함에 따라 연결어미의 다양성과 사용비율이 증가한다고 하였다. 초등학교 저학년 아동을 대상으로 한 본 연구에서도 대등적 연결 어미가 포함된 연결어미의 수행이 종속적 연결어미가 포함된 연결 어미의 수행보다 높게 나타났다. 이는 연결어미의 발달 경향과 유 사하며, 비교적 늦게 발달하는 종속적 연결어미의 사용이 대등적 연결어미의 사용보다 익숙하지 않기 때문인 것으로 보인다. 또한 메 타언어인식 과제를 활용하여 초등학교 1-2학년 읽기부진아동과 일 반아동을 대상으로 연결어미 형태인식 검사를 진행한 선행연구 (Kim, 2015) 결과와 유사하게 종속적 연결어미의 발달이 다른 연결 어미의 발달보다 늦게 나타난다는 것을 메타언어인식 과제를 활용 하여 확인하였다.

또한, 연결어미 인식과제 유형과 연결어미 유형의 상호작용 효과 도 유의하여 연결어미 인식 과제유형별로 일원분산분석을 실시한 결과, 변환과제, 배열과제에서 연결어미 유형 간 차이가 유의하게 나타났다. 이러한 차이는 아동의 구체적인 반응을 요구하는 과제 의 특성에서 나타난 것으로 보인다. 판단과제의 경우 '맞다', '틀리 다'만을 확인하는 비교적 쉬운 과제였기에 연결어미 유형별로 차이 를 보이지 않았고, 수정과제의 경우 부적절한 의미관계의 연결어미 를 정확한 연결어미로 수정하는 그 자체에서도 어려움을 보이기에 연결어미 유형별로 차이를 보이지 않았다. 이러한 결과는 과제에 따라 연결어미의 유형에 대한 인식을 구체적으로 확인해 볼 수 있 다는 점을 시사한다.

연결어미를 통한 전반적인 문법인식을 살펴보고자 한 본 연구에 서 형태소인식에 속하는 과제는 변환과제, 판단과제, 수정과제이 며, 구문인식에 속하는 과제는 배열과제이다. 연구결과 단순언어장 애 위험 아동의 경우 구문인식에 속하는 배열과제에서만 일반 아 동과 유의한 차이가 나타나지 않았다. 이는 배열과제 수행 시에 아 동이 실제 단어카드를 조작하여 반복할 수 있었기 때문으로 보인 다. 하지만 단순언어장애 위험 아동의 오류를 분석해 본 결과 한국 어의 구문구조에 맞지 않게 배열한 오류가 일반 아동에 비해 많았 다. 형태소인식에 속하는 변환과제, 판단과제, 수정과제의 경우 각 과제마다 결과가 달랐지만 공통적으로 단순언어장애 위험 아동은 제시된 형식의 연결어미를 수정하기보다는 의미를 수정하거나, 모 른다고 답하는 경향이 있었다.

연결어미 인식 능력, 어휘력, 구문능력과의 상관관계를 확인한 결과, 단순언어장애 위험 아동의 경우 구문산출능력과 연결어미 인식 능력, 표현어휘력에서 유의한 정적상관을 보였으며, 구문이해 능력과 연결어미 인식 능력, 어휘력에서는 유의한 상관관계가 나타 나지 않았다. 일반 아동의 경우 구문산출능력과 연결어미 인식 능 
력에서만 유의한 정적 상관관계가 나타났다. 어휘력 지연을 보이는 단순언어장애 위험 아동의 경우, 표현어휘력과 구문산출능력이 정 적상관관계로 나타나 단순언어장애 위험 아동일수록 어휘력이 구 문능력에 더 많은 영향을 미치는 것을 확인할 수 있었다. 어휘력 지 연으로 선정한 단순언어장애 위험 아동 집단이 일반아동 집단에 비해 구문능력에서 어려움을 보이는 것은 이들이 구문능력에서 어 려움을 보이는 단순언어장애 아동과 같은 특성을 공유하는 것으 로 볼 수 있다. 구문능력 검사 결과 집단 간 구문이해능력은 두 집 단 모두 높은 수행을 보여 유의한 차이가 나타나지 않았고, 구문산 출능력은 유의한 차이가 나타나 단순언어장애 위험 아동이 일반 아동에 비해 구문산출능력에서 낮은 수행을 보였다. 구문산출능 력은 아동에게 구체적인 반응을 요구한다는 특징이 있다. 이는 단 순언어장애 위험 아동이 구문형식에 대한 지식 부족 등으로 다양 한 언어적 형식을 이해하고 산출하는 것뿐만 아니라 획득한 지식을 활용하는 것에도 오랜 시간이 걸린다는 선행연구(Kamhi \& Koenig, 1985)로 설명할 수 있다. 이러한 결과를 통해 연결어미 인식 능 력을 알아보기 위해서는 연결어미가 포함된 구문이해능력 검사보 다 구문산출능력 검사를 진행하는 것이 효율적이라는 것을 확인 하였다.

본 연구는 연결어미 인식검사라는 메타언어적 형식의 하나인 문 법인식으로 연결어미 인식 능력을 평가하여 일반아동과 다른 단순 언어장애 위험 아동의 특성을 비교 분석한 것에 의의가 있다. 부모 나 교사에 의해 언어문제가 있는 것으로 보고받은 아동 중 어휘력 지연이 있는 아동을 단순언어장애 위험 아동으로 선정하여, 이들 의 구문능력 특성을 통해 학령기 단순언어장애 아동에 대한 이해 에 도움이 되고자 하였다. 연구 결과 단순언어장애 위험 아동은 일 반아동에 비해 연결어미 인식 능력이 낮게 나타났고, 이는 단순언 어장애 아동이 구문능력에 결함을 가지고 있다는 선행연구와 유 사한 특성을 보인다. 다만 연결어미 인식과제 유형에 따라 수행력 도 다르게 나타났기 때문에 후속 연구에서 언어발달 기저의 기억 능력, 처리과정 등도 같이 평가한다면, 이들의 구문능력을 더욱 정 확하게 파악할 수 있을 것이다. 단순언어장애 진단을 위해서는 형 태통사적 요소가 포함된 검사를 진행하는 것이 이들의 변별을 용 이하게 할수 있고(Leonard, 2014), 단순언어장애 위험 아동이 단순 언어장애 아동과 유사한 양상을 보였기에 구문능력을 측정할 수 있는 연결어미 인식검사는 단순언어장애를 변별하기 위한 과제로 도 도움이 될 수 있다. 연구 결과를 통해 문법인식을 활용한 연결어 미 인식검사를 학령기 아동의 구문능력을 다양하게 평가할 수 있 는 도구 중 하나로 선택하여 구문능력을 메타언어적 측면에서도 살펴볼 수 있는 가능성을 확인하였다.
본 연구에서는 총 32 명을 대상으로 연구를 진행하였으나, 연구 의 결과를 일반화하기에는 대상자의 수가 적어 한계가 있다. 후속 연구에서는 대상자의 수를 충분히 확보하고 학년별로 집단을 나누 어 메타언어인식이 학령기에서 지속적으로 발달하는 것을 다양한 조건에서 확인하는 것이 필요할 것이다. 또한 본 연구에서는 연결어 미 인식 능력과 구문이해 및 구문산출능력과의 관계라는 구문적 인 요소를 집중적으로 알아보고자 하였고, 학령기 아동언어검사 (LSSC)의 과제형식과 일부 문항을 사용하였기에 표준화된 어휘력 검사를 진행하여 단순언어장애 위험 아동을 선정하였다. 후속 연 구에서는 보다 다양한 표준화된 언어검사를 진행하여 대상자를 선별하는 것이 필요할 것이다. 마지막으로 후속 연구에서는 보다 다양한 연결어미에 대한 연구가 필요하고, 구문적인 측면에서 연결 어미와 전성어미를 같이 살펴본다면 이어진 문장, 안은 문장 등의 복문을 체계적으로 연구할 수 있을 것이다.

\section{REFERENCES}

Cain, K. (2007). Syntactic awareness and reading ability: is there any evidence for a special relationship? Applied Psycholinguistics, 28, 679-694.

Cho, E. J. (2007). The comprehension and expression ability of connective endings in Korean preschool and school-age children (Master's thesis). Hallym University, Chuncheon, Korea.

Chung, B. J. (2013). Connective endings of 2 to 5 year-old typically developing children. Korean Journal of Early Childhood Special Education, 13, 233246.

Chung, B. J. (2016). Morphological awareness on derivational affixes and related variables in school-aged children (Doctoral dissertation). Ewha Womans University, Seoul, Korea.

Deacon, S. H., \& Kieffer, M. (2018). Understanding how syntactic awareness contributes to reading comprehension: evidence from mediation and longitudinal models. Journal of Educational Psychology, 110, 72-86.

Fehring, R. J. (1987). Methods to validate nursing diagnoses. Heart and Lung, $16,625-629$.

Hardley, P. A., \& Short, H. (2005). The onset of tense marking in children at risk for specific language impairment. Journal of Speech, Language, and Hearing Research, 48, 1344-1362.

Jeong, M. R. (2010). Syntactic awareness skills of poor comprehenders and typically developing children. Korean Journal of Communication \& Disorders, 15, 337-347.

Jung, K. H., \& Pae, S. Y. (2010). The grammaticality judgment in school-aged 
children with specific language impairment. Korean Journal of Communication \& Disorders, 15, 619-631.

Kamhi, A. G. (1987). Metalinguistic abilities in language-impaired children. Topics in Language Disorders, 7, 1-12.

Kamhi, A. G., \& Koenig, L. A. (1985). Metalinguistic awareness in normal and language-disordered children. Language, Speech, and Hearing Services in Schools, 16, 199-210.

Kim, G. E. (2015). Morphological awareness of connective endings in first and second grade poor readers (Master's thesis). Chosun University, Gwangju, Korea.

Kim, J, A. (2002). Production of connective endings of Korean children with and without specific language impairment (Master's thesis). Hallym University, Chuncheon, Korea.

Kim, Y. T., Hong, G. H., Kim, K. H., Jang, H. S., \& Lee, J. Y. (2009). Receptive \& Expressive Vocabulary Test (REVT). Seoul: Seoul Community Rehabilitation Center.

Lee, C. M., Jeong, M. R., \& Hwang, M. A. (2013). Word ordering skills of typically developing children and SLI in elementary school. Journal of Speech \& Hearing Disorders, 22, 147-167.

Lee, Y. K., Heo, H. S., \& Jang, S. M. (2014). Language Scale for School-aged Children (LSSC). Seoul: Hakjisa.

Leonard, L. B. (2014). Children with specific language impairment. Cambridge, MA: The MIT Press.

Marinellie, S. A. (2004). Complex syntax used by school-age children with specific language impairment (SLI) in child-adult conversation. Journal of Communication Disorders, 37, 517-533.

Nam, G. C., Kim, H. J., Park, C. S., Hwang, Y. M., Kim, Y. T., \& Sim, H. S. (2004). The effects of Korean logical ending connective affix on the text comprehension and recall. Korean Journal of Communication \& Disorders, 9, 51-71.

Nam, G. S. (2001). Modern Korean syntax. Paju: Taehaksa.

Nippold, M. A. (2017). Reading comprehension deficits in adolescents: ad- dressing underlying language abilities. Language, Speech, and Hearing Services in Schools, 48, 125-131.

Pae, S. Y. (2006). Grammatical development of Korean young children. Korean Linguistics, 31, 31-45.

Park, H. (2014). Korean Comprehensive Test of Nonverbal Intelligence-Second Edition. Seoul: Mind Press.

Rice, M. L., Wexler, K., \& Redmond, S. M. (1999). Grammaticality judgments of an extended optional infinitive grammar: evidence from English-speaking children with specific language impairment. Journal of Speech, Language, and Hearing Research, 42, 943-961.

Seo, H. S., \& Lee, S. H. (1999). The development of connective endings of 2-5 year old normal children. Korean Journal of Communication \& Disorders, 4, 1-19.

Smith, C. L., \& Tager-Flusberg, H. (1982). Metalinguistic awareness and language development. Journal of Experimental Child Psychology, 34, 449-468.

Tomas, E., Demuth, K., \& Petocz, P. (2017). The role of frequency in learning morphophonological alternations: implications for children with specific language impairment. Journal of Speech, Language, and Hearing Research, 60, 1316-1329.

Tong, X., Deacon, S. H., \& Cain, K. (2014). Morphological and syntactic awareness in poor comprehenders: another piece of the puzzle. Journal of Learning Disabilities, 47, 22-33.

Tsang, K. K., \& Stokes, S. F. (2001). Syntactic awareness of Cantonese-speaking children. Journal of Child Language, 28, 703-739.

Tunmer, W., \& Herriman, M. (1984). The development of metalinguistic awareness: a conceptual overview. In W. Tunmer et al. (Eds.), Metalinguistic awareness in children (pp. 12-35). New York, NY: Springer.

Varghese, R. A., \& Venkatesh, L. (2012). Grammaticality judgement in English among typically developing primary school children: a preliminary investigation. Journal of the All India Institute of Speech \& Hearing, 31, 109119. 
Appendix 1. Examples of Connective Ending Awareness Test

\section{1. 변환과제}

\begin{tabular}{|c|c|c|c|c|c|}
\hline 번호 & 문항 & 제공 단어 & 목표 단어 & 점수 & 반응 \\
\hline 연습 & 아빠는 청소하고 엄마는 설거지한다. & 청소하다 & & & \\
\hline 1 & 엄마는 신문을 __ 영희는 책을 읽는다. & 보다 & 보고 & & \\
\hline 2 & 아빠는 머리를 ___ 철수는 세수한다. & 감다 & 감고 & & \\
\hline 3 & 영희는 그네를 ___ 동생은 모래놀이를 한다. & 타다 & 타고 & & \\
\hline 4 & 영희는 밥을 __ 민수는 우유를 마신다. & 먹다 & 먹고 & & \\
\hline 5 & 영희는 옷을 __ 엄마는 거울을 본다. & 입다 & 입고 & & \\
\hline 연습 & 장난감을 던지면 안된다. & 던지다 & & & \\
\hline 6 & 승주가__정말 무섭다. & 화나다 & 화나면 & & \\
\hline 7 & 가위로__ 위험하다. & 장난치다 & 장난치면 & & \\
\hline 8 & 과일을 많이 ___ 무겁다. & 사다 & 사면 & & \\
\hline 9 & 친구를 __ 안된다. & 때리다 & 때리면 & & \\
\hline 10 & 아이스크림을 많이 ___ 배가 아프다. & 먹다 & 먹으면 & & \\
\hline 연습 & 아빠는 뚱뚱한데 엄마는 날씬하다. & 뚱뚱하다 & & & \\
\hline 11 & 동생은 __ 나는 안 잔다. & 자다 & 자는데 & & \\
\hline 12 & 민아는 ___ 민수는 아프다 & 건강하다 & 건강한데 & & \\
\hline 13 & 지현이는 ___ 은지는 걷는다. & 뛰다 & 뛰는데 & & \\
\hline 14 & 나는 노래를 __ 동생은 노래를 잘한다. & 못하다 & 못하는데 & & \\
\hline 15 & 수리는 키가___서준이는 키가 크다. & 작다 & 작은데 & & \\
\hline 연습 & 장난감이 망가져서 운다. & 망가지다 & & & \\
\hline 16 & 길을 가다가 돌에 __ 넘어졌다. & 걸리다 & 걸려서 & & \\
\hline 17 & 바람이 ___ 모자가 날아갔다. & 불다 & 불어서 & & \\
\hline 18 & 배가 __ 밥을 먹었다. & 고프다 & 고파서 & & \\
\hline 19 & __ 친구랑 놀이터에 갔다. & 심심하다 & 심심해서 & & \\
\hline 20 & 잠이___ 침대에서 잤다. & 오다 & 와서 & & \\
\hline 연습 & 민아와 민수는 학교에 가면서 이야기를 한다. & 가다 & & & \\
\hline 21 & 사과를 ___E텔레비전을 본다. & 먹다 & 먹으면서 & & \\
\hline 22 & 피아노를 __ 노래를 부른다. & 치다 & 치면서 & & \\
\hline 23 & 은정이는 ___ 학교에 간다. & 웃다 & 웃으면서 & & \\
\hline 24 & 민기가 주스를 __ 책을 읽는다. & 마시다 & 마시면서 & & \\
\hline 25 & 음악을 ___춤을 춘다. & 듣다 & 들으면서 & & \\
\hline 연습 & 책을 사려고 서점에 간다. & 사다 & & & \\
\hline 26 & 민아가 선우를 __ 소리를 지른다. & 깨우다 & 깨우려고 & & \\
\hline 27 & 지붕에 __ 사다리를 가져온다. & 올라가다 & 올라가려고 & & \\
\hline 28 & 눈사람을 ___ 운동장에 간다. & 만들다 & 만들려고 & & \\
\hline 29 & 엄마에게 칭찬을 __ 청소를 한다. & 받다 & 받으려고 & & \\
\hline 30 & 친구를 __ 장난을 친다. & 놀리다 & 놀리려고 & & \\
\hline
\end{tabular}

(Continued to the next page) 
Appendix 1. Continued

2. 판단과제와 수정과제

\begin{tabular}{|c|c|c|c|c|c|c|}
\hline \multirow{3}{*}{$\begin{array}{l}\text { 번호 } \\
\text { 연습 }\end{array}$} & \multirow{2}{*}{ 제시문장 } & \multicolumn{3}{|c|}{ 아동반응 } & \multicolumn{2}{|c|}{ 점수 } \\
\hline & & \multicolumn{2}{|c|}{ 판단 } & 수정 & 판단 & 수정 \\
\hline & 누나는 그네를 타려고 동생은 미끄럼틀을 탄다. & 맞아요 & 틀려요 & 타고 & & \\
\hline 연습 & 목이 마르려고 물을 마신다. & 맞아요 & 틀려요 & 말라서 & & \\
\hline 1 & 상진이는 열심히 공부했지만 백점을 맞았다. & 맞아요 & 틀려요 & 공부해서 & & \\
\hline 2 & 사과는 맛있어서 배는 맛이 없다. & 맞아요 & 틀려요 & 맛있는데 & & \\
\hline 3 & 민아는 초록불이 되려고 길을 건넌다. & 맞아요 & 틀려요 & 되면 & & \\
\hline 4 & 물을 꺼냈는데 냉장고를 열었다. & 맞아요 & 틀려요 & 꺼내려고 & & \\
\hline 5 & 상아는 시험에 붙었지만 상진이도 붙었다. & 맞아요 & 틀려요 & 붙었고 & & \\
\hline 6 & 바람이 불어서 나무가 흔들렸다. & 맞아요 & 틀려요 & & & \\
\hline 7 & 손으로 냄비를 만지고 손이 뜨겁다. & 맞아요 & 틀려요 & 만지면 & & \\
\hline 8 & 민아는 웃었지만 달려간다. & 맞아요 & 틀려요 & 웃으면서 & & \\
\hline 9 & 아빠의 모자는 큰데 엄마의 모자는 작다. & 맞아요 & 틀려요 & & & \\
\hline 10 & 동생은 이를 닦고 누나는 머리를 감는다. & 맞아요 & 틀려요 & & & \\
\hline 11 & 민아는 키가 크면서 민수는 키가 작다. & 맞아요 & 틀려요 & 큰데 & & \\
\hline 12 & 벽에 낙서를 하면 엄마한테 혼난다. & 맞아요 & 틀려요 & & & \\
\hline 13 & 엄마는 요리를 하면서 아빠는 청소를 한다. & 맞아요 & 틀려요 & 하고 & & \\
\hline 14 & 누나가 피아노를 치면서 노래를 부른다. & 맞아요 & 틀려요 & & & \\
\hline 15 & 선생님이 되는데 공부를 열심히 한다 & 맞아요 & 틀려요 & 되려고 & & \\
\hline 16 & 아빠는 잠을 자려고 꿈을 꾼다. & 맞아요 & 틀려요 & 자면서 & & \\
\hline 17 & 상아는 공부를 하려고 학교에 간다. & 맞아요 & 틀려요 & & & \\
\hline 18 & 누나가 눈이 나쁘면서 안경을 쓴다. & 맞아요 & 틀려요 & 나빠서 & & \\
\hline
\end{tabular}

\section{3. 배열과제(어절 단위의 단어카드, 단어배열판 제시)}

\begin{tabular}{|c|l|l|}
\hline 번호 & \multicolumn{1}{|c|}{ 제시문장 } & 반응 \\
\hline 연습 & 점수 \\
\hline 연습 & 전화발벨이 울려서 아기가 울었다. \\
\hline 1 & 엄마는 요리하고 아빠는 청소한다. \\
\hline 2 & 텔레비전을 보면서 과자를 먹는다. \\
\hline 3 & 여름은 더운데 겨울은 춥다. \\
\hline 4 & 그네를 타려고 놀이터에 간다. \\
\hline 5 & 눈이 내리면 길이 미끄럽다. \\
\hline 6 & 목이 말라서 물을 마셨다. \\
\hline 7 & 철수는 피아노를 치고 영희는 하모니카를 불었다. \\
\hline 8 & 오빠가 즐겁게 춤을 추면서 음악을 듣는다. \\
\hline 9 & 공부를 열심히 했지만 아깝게 시험에 실패했다. \\
\hline 10 & 누나는 오후에 책을 빌리려고 도서관에 간다. \\
\hline 11 & 우리가 시골에 가면 할머니께서 정류장으로 나오신다. \\
\hline 12 & 언니가 학교에 가서 아기가 혼자 놀았다. \\
\hline
\end{tabular}




\section{국문초록}

\section{초등학교 저학년 단순언어장애 위험 아동의 연결어미 인식 능력 박지혜'(학생, 제1저자) · 김영태'·(교수, 센터장, 교신저자) · 연석정(책임연구원) ${ }^{1}$ 이화여자대학교 언어병리학과, ${ }^{2}$ 이화여자대학교 발달장애아동센터}

배경 및 목적: 본 연구는 구문능력이 정교화되고 문법인식이 지속적으로 발달하는 초등학교 저학년 단순언어장애 위험 아동과 일반 아동을 대상으로 연결어미 인식 능력의 특성을 살펴보고자 하였다. 방법: 초등학교 1-3학년 단순언어장애 위험 아동, 생활연령과 성별 을 일치시킨 일반아동, 총 32 명이 연구에 참여하였다. 연결어미 인식검사는 변환과제, 판단과제, 수정과제, 배열과제의 4 개로 구성되었으 며, 각 과제에 대등적 연결어미와 종속적 연결어미를 동일한 수로 배치하였다. 연결어미 인식 능력을 집단과 과제 유형, 연결어미 유형에 따라 분석하였고, 집단별로 어휘력, 구문이해 및 구문산출능력의 상관을 분석하였다. 결과: 단순언어장애 위험 아동은 일반아동에 비 해 연결어미 인식 능력이 낮은 것으로 나타났으며, 이들의 연결어미 인식 능력은 표현어휘력 및 구문산출능력과 유의한 정적상관관계 가 있는 것으로 나타났다. 논의 및 결론: 어휘력 지연을 보이는 단순언어장애 위험 아동도 단순언어장애 아동과 같이 구문능력에서 어 려움을 보인다는 것을 확인하였으며, 연결어미 인식검사는 학령기 아동의 구문능력을 다양하게 평가할 수 있는 도구로 활용할 수 있다.

핵심어: 단순언어장애 위험 아동, 연결어미, 메타언어인식

\section{참고문헌}

김가은(2015). 초등학교 1-2학년 읽기부진아동의 연결어미 형태인식 능력. 조선대학교 대학원 석사학위논문. 김영태, 홍경훈, 김경희, 장혜성, 이주연(2009). 수용·표현 어휘력 검사(REVT). 서울: 서울장애인종합복지관. 김정아(2002). 정상아동과 단순언어장애아동의 연결어미 사용에 관한 연구. 한림대학교 대학원 석사학위논문. 남기심(2001). (현대) 국어 통사론. 파주: 태학사.

남기춘, 김현정, 박창수, 황유미, 김영태, 심현섭 (2004). 연결어미가 글 이해와 기억에 미치는 효과. 언어청각장애연구, 9, 51-71.

박혜원(2014). 한국 비언어 지능검사-제2판(K-CTONI-2). 서울: 마인드프레스.

배소영(2006). 한국어 발달특성과 학령전기 문법형태소. 한국어학, 31,31-45.

서희선, 이승환(1999). 2-5세 정상아동의 연결어미 발달. 언어청각장애연구, 4, 1-19.

이윤경, 허현숙, 장승민(2014). 학령기 아동언어검사(LSSC). 서울: 학지사.

이찬미, 정미란, 황민아(2013). 학령기 단순언어장애아동과 일반아동의 문장구성하기. 언어치료연구, 22, 147-167.

정경희, 배소영(2010). 초등 저학년 단순언어장애 아동의 문법형태소 판단 능력. 언어청각장애연구, 15, 619-631.

정미란(2010). 초등학교 3-6학년 일반학생과 읽기이해 부진학생의 구문인식 비교: 문장 구성하기 과제를 중심으로. 언어청각장애연구, 15, 337-347.

정부자(2013). 2세에서 5세 일반아동의 자발화에 나타난 연결어미 발달 특성. 유아특수교육연구, 13, 233-246.

정부자(2016). 초등학교 저학년과 중학년 일반아동의 파생어 형태인식 발달 및 예측변인 탐색. 이화여자대학교 대학원 박사학위논문.

조은정(2007). 학령전기와 학령기 아동의 연결어미 이해 및 표현능력. 한림대학교 대학원 석사학위논문. 